\title{
Impact of Credit Access on Crop Farmers' Well-being in Osun State, Southwestern Nigeria
}

\author{
Sodeeq A.E ${ }^{1} \quad$ Saka J.O ${ }^{2} \quad$ Lamidi, L.O ${ }^{1} \quad$ Oguntade, M.I ${ }^{3} \quad$ Adegbuji U.O ${ }^{1}$ \\ 1.Department of Agricultural Extension and Management, Federal College of Animal Health and Production \\ Technology, Moor Plantation, Ibadan. Corresponding author's \\ 2.Institute of Agricultural Research and Training, Moor Plantation, Ibadan. \\ 3.Department of Agricultural Extension and Management, Federal College of Agriculture, \\ Moor Plantation, Ibadan
}

\begin{abstract}
The role of credit in improving the well-being of farmers cannot be overemphasized and it has been discovered to be of great importance for the development of agriculture in Nigeria. Unfortunately, there has been low rate of its accessibility which consequentially affecting well-being of farmers in rural area. This study thus investigated the impact of credit access on crop farmers' well-being in Osun state, Southwestern, Nigeria and data were collected using structured questionnaire administered to 150 farmers selected by multistage sampling techniques. The result shows that the crop farmers were in their active economic productive age with mean age 41years and majority obtained credit from Agricultural Credit Cooperative. Determinant factors influencing crop farmers' access to credit in the study areas were age $(p<0.10)$, marital status $(p<0.05)$ and years of membership in farmers' association $(p<0.01)$ while significant credit variables affecting farmers' well-being were amount of credit needed $(p<0.01)$, credit purpose $(p<0.01)$, credit ration $(p<0.01)$, interest rate $(p<0.10)$ and disbursement lag $(p<0.01)$. Thus, the study recommended that farmers should be encouraged to form groups for credit accessibility and use it for the farming purpose meant for to improve their well-being.
\end{abstract}

Keywords: Credit, Credit Status, Credit Access, Well-being, Crop Farmers.

DOI: $10.7176 / \mathrm{JESD} / 10-4-11$

\subsection{Introduction}

Agriculture has remained the dominant contributor to the rural sector of the Nigerian economy owing to its source of employment to about $60 \%$ of the workforce and array of commodities produced across the different regions of the country. Similarly, the production supported by its high population density, diverse and favourable climatic conditions, rich soil type has placed Nigerian in vantage position in the production of certain crops (notably cassava, yam cowpea), livestock and fishing in Africa (Abdullahi, 2003, Manyong et al, 2005). Today, Agriculture in Nigeria is increasingly recognized as central to sustainable economic development as it plays a very significant role in addressing food insecurity, poverty and human development challenges (Amaza and Maurice, 2005). In the bid to meet food production target however, farmers are particularly in need of credit for investment in agriculture towards expanded production and boosting the country's food self-sufficiency ratio.

According to Adegeye and Dittoh (1985), credit is described as the process of obtaining control over the use of money, good and services in the present in exchange for a promise to repay at a future date. Williams et al. (2007), defined credit as the trust which allows one party to provide resources to another party where that second party does not reimburse the first party immediately, thereby generating a debt, but instead arranges either to repay or return those resources (or other materials of equal value) at a later date. Credits may be financial or they may consist of goods and services (Ashaolu et al., 2011). It accessibility plays a crucial role in agricultural rural development, productivity, growth, economic of scales, food security, utilities to satisfy wider market and standard of living by breaking vicious cycle of poverty (Ololade and Olagunju, 2013; Ayegba, 2013; Ugwumba and Omojola, 2013). Credit has capacity to facilitate optimal input use unlike credit-constrained farmers who are more likely to use lower levels of inputs in production (Omonona et al., 2010; Benjamin et al., 2015). The facilitation of optimal use of inputs generates precursor for increased productivity, income and enhanced wellbeing. Wellbeing has been defined as a dynamic state that is enhanced when people can fulfil their personal and social goals... both in relation to objective measures, such as household income, educational resources and health status; and subjective indicators such as happiness, perceptions of quality of life and life satisfaction (Statham and Chase, 2010). Though, this may depend on the impact of economic activities in which the farmers are involved and what enhances the well-being of a particular farmer may be of negative impact to others.

Most farmers in rural communities live in squalor and very poor standard of living which are attributed to lack of enhanced social well-being or scarcity of human basic needs. This worsening standard of living of farmers in the country can be traced to a number of factors ranging from lack of access to endowments such as employment, education, health care facilities, good food, potable water, proper sanitation system, poor infrastructural development, and inadequate access to land and capital or credit (Bola, 2012). These factors had remained disincentive to most farmers in their effort to increase productivity and improve their well-being (CBN 2002; 
Ugbajah, 2011). In recognition of the importance of credit access to adoption behavior and improved productivity of farmers, there have been several initiatives targeted at facilitating access of farmers to micro-credits. These efforts was more pronounced with the Agricultural Transformation Agenda (ATA) of the immediate past regime with such schemes such as the Growth Enhancement Support (GES) scheme, outgrowers' scheme or contract farming and other programmes targeted at commodity value chain development (infrastructure development, capacity development, science and technology, access to financial services). The targets of these schemes are conspicuously itemized in the policy documents establishing these various schemes, but worthy of focus is the ability of these schemes to achieve the stated objectives. This study is thus designed to assess the status of the access of farmers to credit, its determinants and the effect on well-being of farmers.

\subsection{Methodology}

The study was conducted in Osun State, Southwestern Nigeria. The state comprises of thirty Local Government Areas and it is located between longitudes $4^{\circ} 15^{\prime}$ to $4^{\circ} 45^{\prime}$ east of the Greenwich Meridian and latitude $7^{\circ} 35^{\prime}$ to $7^{\circ} 55^{\prime}$ north of the equator. Osun state lies towards the west and east of Ekiti and Oyo State respectively. It is bounded in the north by Kwara state and in the south by Ondo State respectively. The state exhibits two distinct seasons: these are the rainy season which starts from early or mid-April to October and the dry season from November to March. Primary data were collected for this study with the aid of well-structured questionnaire from 150 farmers selected by multi-stage sampling technique. The first stage was random selection of one Osun State Agricultural Development Programme (OSSADEP) zone. The second stage was random selection of three local government areas from the zone while the third stage was random selection of one hundred and fifty farmers from the list of farmers obtained in OSSADEP office for the study. Data collected were analyzed using descriptive statistics such as frequencies, percentages and means while logit and tobit regressions were specified to examine the determinants of credit access and the effect on well-being of farmers respectively

\subsection{Analytical Framework}

\subsection{Logit Regression Model}

The term "logit" refers to the natural logarithm of the odds (log odds) which indicates the probability of falling into one of two categories on some variable of interest (Wooldridge, 2009).It is a univariate binary model use given that the dependent variable is dichotomous. According to Harrell (2001), binary logit has only two categories in the response variable, that is, 0 when a farmer is having no access to credit and 1 when having access to credit. In this study, since only two options are available, namely "access to credit" or "no access to credit" a binary model will be set up to define $Y=1$ for situation where the farmer accessed credit and $Y=0$ for situations where the farmer did not access credit from either formal or informal credit sources. Predictor variables are a set of socioeconomic and demographic status indicators and dwelling endowment of the farmers. They contain both dichotomous and continuous variables. Assuming that $\mathrm{X}$ is a vector of explanatory variables and $p$ is the probability that $\mathrm{Y}=1$, two probabilistic relationships as stated by Wooldridge (2009) can be considered as follows:

$$
\begin{aligned}
& P(Y=1)=\frac{e^{\beta x}}{1+e^{\beta x}} \\
& P(Y=0)=1-\frac{e^{\beta x}}{1+e^{\beta x}}=\frac{1}{1+e^{\beta x}}
\end{aligned}
$$

Woodridge (2009) concluded that since Equation (2) is the lower response level, that is, the probability that farmers did not access credit from formal and informal credit source, this will be the probability to be modeled by the logistic procedure by convention. The equation presents the outcome of the logit transformation of the odds ratios which can alternatively be represented as:

$$
\log i t[\theta(x)]=\log \left[\frac{\theta(x)}{1-\theta(x)}\right]=\alpha+\beta_{1} x_{1}+\beta_{2} x_{2}+\ldots \beta_{k} x_{k}
$$

and thus allowing its estimation as a linear model for which the following definitions apply: $\theta=$ logit transformation of the odds ratio; $\dot{\alpha}=$ the intercept term of the model; $\beta=$ the regression coefficient or slope of the individual predictor (or explanatory) variables modeled and $\mathrm{Xi}=$ the explanatory or predictor variables. In relation to Equation (3) the analysis will generate the odd ratios using the maximum likelihood procedure (Field, 2005). The logistic regression in this study can be specified as:

$$
Y i=\alpha+\beta_{1} x_{1}+\beta_{2} x_{2}+\beta_{3} x_{3}+\beta_{4} x_{4}+\beta_{5} x_{5}+\beta_{6} x_{6}+\beta_{7} x_{7}+\mu
$$

where, $\mathrm{Yi}=$ the dependent variable defined as the access to credit by crop farmers $=1$ and 0 otherwise; $\alpha=$ constant and intercept of the equation; $\mathrm{X}_{1}=$ age of farmers in years; $\mathrm{X}_{2}=$ marital status of farmers $(1=$ single, $2=$ married, 
$3=$ divorced and $4=$ widow/widower) $; X_{3}=$ household size; $X_{4}=$ education in years; $X_{5}=$ membership of farmers association(years); $\mathrm{X}_{6}=$ experience in years; $\mathrm{X}_{7}=$ total income from farming per year (naira) and $\mathrm{U}_{\mathrm{k}}=$ error term.

\subsection{Tobit Regression Model}

Tobit regression model which was originally developed by Tobin (1958) and used by many researchers such as Adejobi (2004), Austin and Edward (2003), Omonona (2000) and Rahji (1999) has been described as an extension of Probit model (Gujarati, 2004). The model was used to evaluate effect of credit on well-being of farmers. It is explicitly expressed as follow:

$Y i=\alpha+\beta_{1} x_{1}+\beta_{2} x_{2}+\beta_{3} x_{3}+\beta_{4} x_{4}+\beta_{5} x_{5}+\beta_{6} x_{6}+\beta_{7} x_{7}+\mu$

Where; $Y=$ Farmers' well-being score ; $\beta_{0}$ is the intercept and $\beta_{1}-\beta_{8}$ are the regression coefficients that explain the effect of credit on well-being; $\mu_{\text {is }}$ the error term while $\mathrm{X}_{1}-\mathrm{X}_{8}$ are the independent variables specified and defined below: $\mathrm{X}_{1}=$ Amount of credit needed in naira; $\mathrm{X}_{2}=$ Credit purpose (farming $=1$, non-farming $=2$, both $=$ 0 ); $X_{3}=$ Borrowing experience (if satisfactory $=1$, otherwise $=0$ ); $X_{4}=$ Credit ration (received amount applied for $=1$, otherwise $=0) ; X_{5}=$ Interest rate in percentage; $X_{6}=$ Collateral security (if yes $=1$, otherwise $=0$ ); $X_{7}=$ Disbursement lags (if timely $=1$, otherwise $=0$ ); $\mathrm{X}_{8}=$ Repayment period in months; $\mu$ = Error term.

\subsection{Results and Discussion}

\subsection{Personal Characteristic of Farmers}

Table 1 shows that the mean age of the crop farmers in the study area was 41 years but specifically, $38.7 \%$ were in the age range $31-40$ years, $26.7 \%$ were between $41-50$ years and $20.0 \%$ were above 50 years of age. This indicates that about $80.0 \%$ of the respondents fall within the age group of 50 years or less. Oyediran et al. (2013) opined that respondents in this category are within the economically active population and therefore constitute a good labour force with the expectation that they would be good managers of limited available resources and can withstand rigors associated with farming activities. About $83.0 \%$ were male and $17.3 \%$ were female. The low percentage of women might be because crop production is considered men's job as women folks dominate processing and marketing.

Also, $80.0 \%$ of the farmers in the study area were married, $46.7 \%$ had secondary education while $38.7 \%$ had tertiary education. Asiabaka (2002) revealed that educational level is a very important determinant in adoption of innovation. Majority (44.0\%) of the farmers had 4-6 members, 30.0\% between 7-9 members while 18.0\% had 1-3 members. The mean household size was 6 members and Agbamu (2000) stated that the large number of persons in a family pave way for use of family labour in farming enterprise. In terms of experience, $42.7 \%$ of the farmers had 6-10 years of experience and $32.0 \%$ had $1-5$ years. The mean experience was approximately 8 years. This shows that the respondents were relatively not new in the crop production business and crop farming is not a new means of livelihood to the people in the study area as their mean farm size was 2 acres and $86.7 \%$ were members of farmers association. Sodeeq et.al, (2016) reported that more experienced farmer could predict the future outcome of production with some probability by considering performance of past years. 
Table 1: Personal Characteristic of Crop Farmers in the Study Area.

\begin{tabular}{|c|c|c|}
\hline Variable & Frequency $(\mathrm{n}=150)$ & Percentage \\
\hline \multicolumn{3}{|l|}{ Age in years } \\
\hline $21-30$ & 22 & 14.6 \\
\hline $31-40$ & 58 & 38.7 \\
\hline $41-50$ & 40 & 26.7 \\
\hline$>50$ & 30 & 20.0 \\
\hline Mean & 41 & \\
\hline \multicolumn{3}{|l|}{ Sex } \\
\hline Male & 124 & 82.7 \\
\hline Female & 26 & 17.3 \\
\hline \multicolumn{3}{|l|}{ Marital Status } \\
\hline Single & 18 & 12.0 \\
\hline Married & 120 & 80.0 \\
\hline Divorced & 8 & 5.3 \\
\hline Widow & 4 & 2.7 \\
\hline \multicolumn{3}{|l|}{ Education } \\
\hline Primary & 22 & 14.6 \\
\hline Secondary & 70 & 46.7 \\
\hline Tertiary & 58 & 38.7 \\
\hline \multicolumn{3}{|c|}{ Household size } \\
\hline $1-3$ & 27 & 18.0 \\
\hline $4-6$ & 66 & 44.0 \\
\hline $7-9$ & 45 & 30.0 \\
\hline $10-12$ & 12 & 8.0 \\
\hline Mean & 6 & \\
\hline \multicolumn{3}{|l|}{ Experience } \\
\hline $1-5$ & 48 & 32.0 \\
\hline $6-10$ & 64 & 42.7 \\
\hline $11-15$ & 27 & 18.0 \\
\hline 15 and above & 11 & 7.3 \\
\hline Mean & 8 & \\
\hline \multicolumn{3}{|c|}{ Farm Size (acres) } \\
\hline 1 & 76 & 50.7 \\
\hline 2 & 34 & 22.7 \\
\hline 3 & 40 & 26.7 \\
\hline Mean & 2 & \\
\hline
\end{tabular}

Source: Field Survey, 2018.

\subsection{Information on Credit Status of Crop Farmers}

Table 2 reveals that $23.3 \%$ of crop farmers obtained credit from Agricultural Credit Cooperative, $20.0 \%$ obtained from farmers' association and $13.3 \%$ of the farmers obtained credit from relatives and families. This result is in consonance with Adebayo and Adeola (2008) who opined that cooperative society was the most source of credit to famers and contrary to the study carried out in Nsukka Local Government Area of Enugu State by Akinnagbe and Adonu, (2014) which revealed that majority of farmers got their credit through friends and relations. Higher percentage $(34.6 \%)$ of farmers had received credit 1-6 times while others $(22.0 \%)$ had received for more times. However, only $26.7 \%$ of farmers obtained credit for farming purpose, $16.6 \%$ obtained for paying school fees while $3.3 \%$ obtained credit for purpose of meeting social ceremony obligations. Similar finding of credit diversion was reported by Anyiro and Oriaku (2011) and this habit could have a negative impact on well-being. On the amount of loans applied for and obtained by farmer, $26.7 \%$ applied for $\$ 300,000$ or less, $16.6 \%$ applied for $\$ 301,000$ $\$ 400,000$ and others applied for more than $\$ 400,000$.Approximately seventeen percent $(17.3 \%)$ received $\$ 201,000$ - $\$ 250,000,12.7 \%$ received $\$ 151,000-\$ 200,000$ and $10.6 \%$ received less than $\$ 50,000$. About $34.0 \%$ of the farmer claimed that interest rate on credit received was between $6-25 \%$ and $40.0 \%$ claimed collateral was through guarantor. 
Table 2: Information on Credit Status of Crop Farmers

\begin{tabular}{|c|c|c|}
\hline Variable & Frequency $(\mathrm{n}=150)$ & Percentage $(\%)$ \\
\hline \multicolumn{3}{|l|}{ Sources of Credit } \\
\hline None & 65 & 43.4 \\
\hline Farmers association & 30 & 20.0 \\
\hline Agric. credit cooperative & 35 & 23.3 \\
\hline Relative and family & 20 & 13.3 \\
\hline \multicolumn{3}{|l|}{ No of Time Loan Received } \\
\hline None & 65 & 43.4 \\
\hline $1-3$ & 36 & 24.0 \\
\hline $4-6$ & 16 & 10.6 \\
\hline 7-9 & 10 & 6.7 \\
\hline $10-12$ & 14 & 9.3 \\
\hline $13-15$ & 9 & 6.0 \\
\hline \multicolumn{3}{|l|}{ Purpose of Credit } \\
\hline None & 65 & 43.4 \\
\hline Farming & 40 & 26.7 \\
\hline Payment of child school fees & 25 & 16.6 \\
\hline Social ceremony obligations & 5 & 3.3 \\
\hline Building & 15 & 10.0 \\
\hline \multicolumn{3}{|l|}{ Amount of Loan Needed } \\
\hline None & 65 & 43.4 \\
\hline$\leq 300,000$ & 40 & 26.7 \\
\hline $301,000-400,000$ & 25 & 16.6 \\
\hline $401,000-500,000$ & 10 & 6.7 \\
\hline $501,000-600,000$ & 7 & 4.6 \\
\hline$>600,000$ & 3 & 2.0 \\
\hline \multicolumn{3}{|l|}{ Amount of Loan Received } \\
\hline None & 65 & 43.4 \\
\hline$\leq 50,000$ & 16 & 10.6 \\
\hline $51,000-100,000$ & 10 & 6.7 \\
\hline $101,000-150,000$ & 14 & 9.3 \\
\hline $151,000-200,000$ & 19 & 12.7 \\
\hline $201,000-250,000$ & 26 & 17.3 \\
\hline \multicolumn{3}{|l|}{ Interest Rate } \\
\hline None & 65 & 43.4 \\
\hline$<5$ & 22 & 14.6 \\
\hline $6-25$ & 50 & 33.3 \\
\hline $26-40$ & 13 & 8.7 \\
\hline \multicolumn{3}{|l|}{ Security } \\
\hline None & 65 & 43.4 \\
\hline Guarantor & 60 & 40.0 \\
\hline Farm land & 20 & 13.3 \\
\hline Landed property & 5 & 3.3 \\
\hline
\end{tabular}

Source: Field Survey, 2018.

4.3 Determinants of Credit Access by Crop Farmers in the Study Area.

Table 3 reveals determinant factors influencing crop farmers' access to credit in the study areas using logistic regression analysis. Age, marital status and membership of farmers' association in years were found significant at $10 \%, 5 \%$ and $1 \%$ respectively. Similar result was reported by Kiplimoet.al.,(2015)who concluded that marital status and membership had significant effect on access to credit. Age and marital status were negatively related to farmers' access to credit while year of membership was positive. As age of the farmer increases, the probability of access to credit reduces by $2.4 \%$ and this implies that younger farmers have access to credit more than the older farmers. Not being married reduces the probability of access to credit by $86.3 \%$ and this might be due to the fact that they are the majority group. Also, increase in years of membership increases the probability of access to credit by $56.07 \%$ and this means that new members are not likely to have access to credit until their commitment are ascertain. Nwankwo (2017) estimates shows that these were very important socioeconomic determinant variables of access to agricultural loan. However, household size, education, experience and income were not significant factors influencing crop farmers' access to credit. 
Table 3: Factors Influencing Credit Access of Crop Farmers in the Study Area.

\begin{tabular}{lllll}
\hline Variable & Coeff. & Std. Error & t-ratio & p-value \\
\hline Constant & 0500407 & 1.1532 & 0.433943 & 0.66433 \\
Age & -0.0244 & 0.0124 & 1.1017 & $0.065758^{*}$ \\
Marital status & -0.8632 & 0.4362 & -1.9786 & $0.047858^{* *}$ \\
Household size & -0.0418 & 0.0362 & 0.8058 & 0.437316 \\
Education & -0.0299 & 0.0305 & -0.97953 & 0.327316 \\
Membership & 0.5607 & 0.1266 & 11.1932 & $0.00123^{* * *}$ \\
Experience & -0.0042 & 0.0139 & -0.29953 & 0.76453 \\
Income & 0.2828 & 0.2935 & -0.96356 & 0.335267 \\
\hline
\end{tabular}

Source: Field Survey, 2018.

\subsection{Well-being Status of Crop Farmers in the Study Area.}

The level of well-being is made up of various components that cannot be solely approximated through economic indicators. Areas of well-being range from the need of adequate income to meet basic needs to people's social involvement and interactions with others. Deprivation in one area can have significant impacts on the overall wellbeing of individuals and household. The human well-being indicators as stated in "human resources and skills development, indicators of well-being, Canada" include housing status, education status, income status, health facilities status, safety and security status as well as social cohesion status is presented in table 4 . The result reveals that safety and security of farmers $(\bar{\chi}=4.28)$ and their social cohesion $(\bar{\chi}=4.26)$ in the area were very good as no cases of crime, violence, social vices and rancor reported. This indicates that there is harmonious and peaceful coexistence between families in the area irrespective of affiliations. It is important to note that perception of safety and protection from harm is a key supporting pillar for well-being and communities with high crime rates do not enjoy the same quality of life as those in more safe communities (Gannon and Mihorean, 2004). Education facilities status $(\bar{\chi}=2.51)$ of farmers were good. This shows that the challenge of farmers with no formal education is gradually diminishing over the past years as access to education is improving significantly in remote areas. Education provides knowledge and opens door to new opportunities that can improve individual living standard. However, income status $(\bar{\chi}=2.36)$ and housing facilities $(\bar{\chi}=2.16)$ of farmers in the areas were poor. A safe comfortable place to live is fundamental to individual sense of well-being. These make farmers in dire need of credit to meet up with their well-being demands in order to improve their low standard of living. The health facilities status ( $\bar{\chi}=2.10$ ) was very poor as most farmers visit native doctor or distance maternity clinic in case of ill health. This indicates poor well-being because good health is a key aspect of overall well-being.

Table 4: Well-being Status of Crop Farmers in the Study Area.

\begin{tabular}{lllllll}
\hline WIVS & V.G & G & F & P & V.P & W.M \\
\hline Housing facilities status & 5 & 10 & 36 & 52 & 47 & 2.16 \\
Education facilities status & 38 & 55 & 22 & 15 & 20 & 3.51 \\
Income status & 5 & 8 & 48 & 64 & 25 & 2.36 \\
Health Facilities status & 10 & 16 & 23 & 31 & 70 & 2.10 \\
Safety and Security status & 78 & 50 & 12 & 6 & 4 & 4.28 \\
Social Cohesion status & 80 & 42 & 18 & 7 & 3 & 4.26 \\
\hline
\end{tabular}

Source: Field Survey, 2018.WIVS- welfare indicator variable status, V.G- very good, G- good, F- fair, P-poor, V.P- very poor and W.M- weighted mean

\subsection{Effect of Credit on Well-being of Farmers in the Study Area.}

Effect of credit variables on well-being of farmers in the study area is presented in table 5. The amount of credit needed was found negative and significant $(p<0.01)$. This means that as the amount of credit needed by farmer increases, their well-being decreases. This might be due to high interest rate and other cost associated with credit application process in the study area. High demand for credit can be an indicator that a farmer lack self-financing and some necessary elements of well-being. The interest rate on credit obtained by farmers was found negative and significant $(\mathrm{p}<0.10)$ indicating that as percentage of interest rate on credit increases, the lesser the well-being of farmer in the study area. This is because during repayment period, high interest rate consumes profit which would have been used by farmers to improve their standard of living.

However, the coefficient of credit purpose was positive and significant $(\mathrm{p}<0.01)$ implying as farmers get credit for the purpose of increasing fixed investment, there is tendency that their well-being improve. This means that the farmers are doing well in business and will be better off in the long-run. Similarly, the coefficient of credit ration and disbursement lag were positive and significant $(p<0.01)$. This implies that as farmers who timely get amount of credit applied for are more likely to have and improved well-being. This is because the credit will be 
enough to cater for their timely needs and help achieve desired result which is an improve standard of living. Other variables fitted into this model such as borrowing experience, value of collateral and repayment period were found negative but not significantly affect well-being of farmers in the study area.

Table 5: Effect of Credit on Well-being of Farmers in the Study Area.

\begin{tabular}{lllll}
\hline Variable & Coeff. & Std. Error & t-ratio & p-value \\
\hline Constant & 0.8111 & 0.3468 & 2.3384 & 0.0194 \\
Amount of credit needed & -0.0170 & 0.0067 & -2.5352 & $0.0112^{* * *}$ \\
Credit purpose & 0.0914 & 0.0342 & 2.6721 & $0.0075^{* * *}$ \\
Borrowing experience & -0.0418 & 0.0362 & 0.8058 & 0.4373 \\
Credit ration & 0.0470 & 0.0096 & 4.8899 & $0.0000^{* * *}$ \\
Interest rate & -0.0147 & 0.0087 & -1.6916 & $0.0907^{*}$ \\
Collateral & -0.0042 & 0.0139 & -0.29953 & 0.7645 \\
Disbursement lag & -0.3791 & 0.1230 & -3.0813 & $0.0021^{* * *}$ \\
Repayment period & -0.0227 & 0.0314 & -0.7219 & 0.4703 \\
\hline
\end{tabular}

Source: Field Survey, 2018.

\subsection{Conclusion and Recommendation \\ 5.1 Conclusion}

The findings of this study revealed that the crop farmers were in their active economic productive age with mean age 41year, educated and cultivating 2 acres of land on average. Majority mostly depend on credit worth N201,000N250,000 from Agricultural Credit Cooperative. The amount not sufficient to meet their farming needs and untimely in disbursement with high interest rate. Significant factors determining crop farmers' access to credit in the study area were age $(\mathrm{p}<0.10)$, marital status $(\mathrm{p}<0.05)$ and membership $(\mathrm{p}<0.01)$ of farmers' association. However, amount of credit needed, borrowing experience, interest rate, collateral, disbursement lag and repayment period had negative effect on farmers' well-being while credit purpose and credit ration had positive effect on farmers' well-being.

\subsection{Recommendation}

In line with the findings of this study, the following recommendations are suggested to improve the impact of credit access on crop farmers' well-being:

- Farmers should form groups for credit accessibility with equal and fair distribution.

- Credit worth enough to meet credit purpose of these farmers should be given to them as this is the only way they can experience positive impact of credit on their production as well as improvement on their well-being.

- Government, agency or institution in charge of disbursing credit to farmers should make it more accessible and reduce interest charged.

- Finally, farmers should stop the habit of diverting credit meant for farming purpose to other purposes in order to achieve the aim of improving well-being.

\section{References}

Abdullahi (2003), "Employment Creation and Opportunities in the Agro-allied Sector: The Case of Cassava Production" CBN bullion publication, 27(4),10.

Adebayo, O.O and Adeola, R.G (2008), "Sources and Uses of Agricultural Credit by Small Scale Farmers in Surulere Local Government Area of Oyo State". Anthropologist, 10(4), 313-314.

Adegeye, A.J. and Dittoh J.S. (1985), "Essential of Agricultural Economics", Ibadan: Impact Publishers, Nigeria, Ltd. 183.

Adejobi, A.O. (2004), "Rural Poverty, Food Production and Demand in Kebbi State, Nigeria", Unpublished PhD Thesis, Department of Agricultural Economics, University of Ibadan.

Agbamu, J.U. (2000), “Agricultural Research-extension Linkage System: An International Perspective", Agricultural research and extension network paper no 106a, Oversees Development Institute, London, 5pp, In Problems and Prospects of Agricultural Extension Services in Developing Countries by J.U agbamu. Agricultural extension in Nigeria.AESON, 159-169pp.

Akinnagbe, O. M. and Adonu, A. U. (2014), "Rural Farmers Sources and Use of Credit in Nsukka Local Government Area of Enugu State, Nigeria", Asian Journal of Agricultural Research, 8, 195-203.

Amaza, P.S. and Maurice, D.C (2005), "Identification of Factors that Influence Technical Efficiency in Rice Based Production System in Nigeria", Paper presented at workshop and food security in sub-Sahram Africa: November 2005, Cotonou (Benin) PP 7-9.

Anyiro, C.O. and Oriaku, B.N (2011), "Access to and Investment of Formal Micro Credit by Small Holder Farmers in Abia State, Nigeria; A Case Study Of Absu Micro Finance Bank", Uturu. The journal of agricultural sciences, 2011, vol.6, no2. 
Ashaolu O. F., Mamioh S., Philip B. B. and Tijani I. A. (2011), "Microcredit Effect on Agricultural Productions: A Comparative Analysis of Rural Farmers in Ogun State, Nigeria", International Journal of Applied Agricultural Research, 7(1): 20-31.

Asilabaka, C.C. (2002), Agricultural Extension: A handbook for development practitioners. Omoku, Molsyfem Publishers.

Austin and Edward (2003), "Use of the Tobit Model for Analyzing Measures of Health Status", The Qual Life, 8: 901-910. Institute for Clinical Evaluative Science (ICES).

Ayegba, O. and Ikani, D. I. (2013), “An Impact Assessment of Agricultural Credit on Rural Farmers in Nigeria”, Research Journal of Finance and Accounting, 4(18), 80-89.

Benjamin TA, Timo Stefan B, Jukka K (2015), “Factors Influencing Smallholder Farmers' Access to Agricultural Credit in Northern Ghana", African Journal Agricultural Research, 10 (24), 2460-2469.

Bola, A.W. (2012), Poverty and Income Inequality Among Fish Farming Households in Oyo State, Nigeria. Medwell Agric. J., 7 (2):100-101.

Central Bank of Nigeria (2002), "Baseline Survey of Micro -Financial Institutions in Nigeria", Lagos: $C B N$ Publications.

Field A (2005), Discovering Statistics Using SPSS (2nd Ed.), London: Sage.

Gannon, M. and Mihorean, K. (2004), "Criminal Victimization in Canada”, Statistics Canada, Juristat, 25(7), Ottawa: Statistics Canada.

Gujarati, D.N. (2004), Basic Econometrics, 4th Ed. New York: Tata Graw - Hill Publishing Co. Ltd.

Harrell Jr. FE (2001), "Regression Modeling Strategies with Applications to Linear Models", Logistic Regression and Survival Analysis. Springer-Verlag, New York.

Kiplimo, J. C, Ngenoh, Bett, J.K. (2015), "Evaluation of Factors Influencing Access to Credit Financial Services: Evidence from Smallholder Farmers in Eastern Region of Kenya. Journal of Economics and Sustainable Development, 6(17).

Manyong VM, IKP, A, Olayemi JK, Yusuf SA, Omonona BT, Okoruwa V, Idachaba FS (2005), “Agriculture in Nigeria; Identifying Opportunity for Increased in Commercialization and Investment”, IITA, Ibadan .Pg 159.

Nwankwo, F.O (2017), "Factors Affecting Access to Agricultural Loans in Anambra State: An Econometric Analysis", Asian Journal of Economics, Business and Accounting, 4(3): 1-8.

Ololade RA, Olagunju FI (2013), "Determinants of Access to Credit among Rural Farmers in Oyo State, Nigeria", Global J. Sci. Frontier Research, Agric. Vet. Sci. 13(2),16-22.

Omonona BT, Lawal JO, Oyinlana AO (2010), "Determinants of Credit Constraint Conditions and Production Efficiency among Farming Households in Southwestern Nigeria", African Association of Agricultural Economists (AAAE), 2010 AAAE Third Conference/AEASA 48 th Conference, September 19-23, 2010, Cape Town, South Africa. http://purl.umn.edu/95775

Omonona, B.T (2000), "Poverty and Its Correlates among Rural Farming Households in Kogi State", Unpublished Ph.D Thesis, Department of Agricultural Economics, University of Ibadan, Nigeria.

Oyediran, W.O., Omoare A.M., Sodiya C.I. and Fakoya E.O. (2013), "Capacity Building for Rural Youth: Priority for Sustainable Catfish Production in Ogun State, Nigeria”, Journal of Agriculture and Veterinary Science (IOSR-JAVS), 4(2), 38-42.

Rahji M. A. Y (1999), "Factors Influencing the Level and Intensity of Adoption of Animal Traction Technology in Bauchi State, Nigeria", Centrepoint Science Edition, 9 (1), 30-41.

Sodeeq Abdulrahman Enesi, Ashaolu Olumuyiwa Fowowe, Salawu Mutiat Bukola, Orumwense Lucy Adeteju (2016), "Economic Evaluation of Private Nursery Enterprises in Oyo State, South-Western Nigeria", International Journal of Agriculture and Environmental Research. 2(4).

Statham, J. and Chase, E. (2010), "Child Wellbeing: A Brief Overview", Childhood Wellbeing Research Centre Briefing Paper, London Institute of Education.http://www.navo.org.uk/downloads/documents/FinalChildDFEwebsite.

Tobin, J. (1958), "Estimation of Relationships for Limited Dependent Variables, Econometrica, 26, 24-36. United Nations. 2012. "Millenium Development Goals Report 2012" http://www.un.org/millenniumgoals/pdf/MDG\%20Report\%202012.pdf.

Ugbajah, M.O (2011), "Gender Analysis of the Structure and Effects of Access to Financial Services among Rural Farmers in Anambra State, Nigeria”, J Agri Sci, 2(2), 107-111.

Ugwumba, COA and Omojola, IT (2013), "Determinant of Loan Repayment of Livestock Farmers Under Agricultural Guarantee Scheme (A.C.G.S) in Etche Local Government Area of Rivers State, Nigeria”, Agricultural Advances. www.sjournals.com

William S. B., Ajaro A. O. and Ogumniyi L. T. (2007), "The Impact of Micro Credit on Food Production in Osun State, Nigeria. Agricultural Journal, 2(2), 301-323.

Wooldridge J.M (2009), Introductory Econometrics, A Modern Approach, Fourth edition. Michigan State University. 